\title{
Elevated level of Interleukin-35 in colorectal cancer induces conversion of $T$ cells into iTr35 by activating STAT1/STAT3
}

\author{
Yanhui Ma ${ }^{1, *}$, Lei Chen ${ }^{2, *}$, Guohua Xie ${ }^{1}$, Yunlan Zhou $^{1}$, Chaoyan Yue ${ }^{1}$, Xiangliang \\ Yuan ${ }^{1}$, Yingxia Zheng ${ }^{1}$, Weiwei Wang ${ }^{1}$, Lin Deng ${ }^{1}$, Lisong Shen ${ }^{1}$ \\ ${ }^{1}$ Department of Laboratory Medicine, Xinhua Hospital, School of Medicine, Shanghai Jiao Tong University, Shanghai 200092, \\ China \\ ${ }^{2}$ Department of General Surgery, Xinhua Hospital, School of Medicine, Shanghai Jiao Tong University, Shanghai 200092, \\ China \\ *These authors contributed equally to this work
}

Correspondence to: Lisong Shen, email: lisongshen@hotmail.com

Keywords: interleukin-35, colorectal cancer, STAT1, STAT3

Received: January 11, $2016 \quad$ Accepted: September 12, $2016 \quad$ Published: September 22, 2016

\section{ABSTRACT}

IL-35 is a novel heterodimeric and inhibitory cytokine, composed of interleukin-12 subunit alpha (P35) and Epstein-Barr virus -induced gene 3 (EBI3). IL-35 has been reported to be produced by a range of cell types, especially regulatory $\mathrm{T}$ cells, and to exert immunosuppressive effects via the STATx signaling pathway. In this study, we demonstrated that IL-35 expression was elevated in both serum and tumors in patients with colorectal cancer. IL-35 mainly expressed in CD4 ${ }^{+} \mathrm{T}$ cells in human colorectal cancer tumors and adjacent tissues. Increased IL-35 expression in tumoradjacent tissues was significantly associated with tumor metastasis. IL-35 inhibited the proliferation of $\mathrm{CD}^{+}{ }^{+} \mathrm{CD} 25^{-} \mathrm{T}$ effector cells in vitro in a dose-dependent manner, and its suppression was partially reversed by applying IL-35-neutralizing antibodies. IL-35 treatment activated the phosphorylation of both STAT1 and STAT3 in human CD4 ${ }^{+}$T cells. Meanwhile, IL-35 induced a positive feedback loop to promote its own production. We observed that Tregs obtained from colorectal cancer patients were capable of inducing more IL-35 production. In addition, EBI3 promoter-driven luciferase activity was higher than that of the mock plasmid after IL-35stimulation. Thus, our study indicates that the high level of IL-35 in colorectal cancer promotes the production of IL-35 via STAT1 and STAT3, which suppresses T cell proliferation and may participate in tumor immunotolerance.

\section{INTRODUCTION}

Colorectal cancer (CRC) is the third most common cancer in men and the second most common cancer in women worldwide [1-3]. The ability to evade immune destruction is one of the hallmarks of cancer [4], and regulatory $\mathrm{T}$ (Treg) cells are a critical sub-population of $\mathrm{CD}^{+} \mathrm{T}$ cells for maintaining self-tolerance and preventing autoimmunity $[5,6]$. Some studies have indicated that an increased number of regulatory $\mathrm{T}$ cells in the blood and tumors of colorectal cancer patients may result in an immune-compromised state against cancer. These studies suggest that strategies to overcome regulatory $\mathrm{T}$ cell activity may be beneficial in treatments for human colorectal cancer [7-9].

IL-35 as an inhibitory cytokine that was shown to be specifically produced by Treg cells in early studies, and is required for maximal suppressive activity in Tregs $[10,11]$. But it has since been reported to be produced in B cells [12] and tumor cells (B lymphoma) [13] as well. IL-35 suppresses immune responses by expanding regulatory $\mathrm{T}$ cell development and suppressing Th17 cell development $[10,11]$. Detectable levels of IL-35 have been reported in patients with chronic hepatitis [14], ulcerative colitis [10], and pancreatic ductal adenocarcinoma [15]. A mathematical model was used 
to show that IL-35 promoted tumorigenesis in colorectal cancer [16]. Because these results were based on a computer analysis, laboratory-based evidence for the role of IL-35 and/or iTr35 in cancer was needed to support their relationship and functions in humans.

In mice, IL-35 exerts its immunosuppressive role via EBI3 subunits, and by binding to its ligand, it downregulates the expression of IL-17, IL-22 and ROR $\gamma t$ [17]. IL-35 also converts Foxp $3^{-} \mathrm{CD}^{+} \mathrm{T}$ cells into inducible Tregs (iTregs) and promotes the expression of IL-35 via a positive feedback loop to involve in immunoregulation [11]. In vivo results in mice confirmed that Tregs secreted IL-35 and induced conventional T cells (Tconv) to iTregs, called iTr35 cells, independent on IL-10 and TGF- $\beta[11,18]$. However, the results supporting the association between human IL-35 and iTr35 cells have varied. One study showed that human Tregs inhibited the immune reaction mediated by IL-35 through inducing Tconv cells into iTr35 cells [11]. In addition, IL-35 suppressed the MAPK-AP-1 pathway in endothelial cell [19]. However, this process has not yet been further explored in human diseases.

The expression and regulation of IL-35 is regulated by its ligand and downstream signal pathway. Studies have reported that the IL-35 receptor (IL-35R) can be a heterodimer containing both IL-12R $\beta 2$ and gpl30 (also IL-6 signal transducer, Il6st) and activate STAT $1 / 4$, or can be homodimer containing either IL-12R $\beta 2$ or gp130 and activate STAT1 or STAT4 separately [20]. Wang et al. [21] found that IL-35 in T cells was capable of activating STAT3 and STAT1/4, but the activation of STAT1 and STAT3 was mediated by a heterodimeric receptor composed of IL-12R $\beta 2$ and IL-27R $\alpha$ in B cells. These studies were performed in mice, however.

In this study, we found high levels of expression of IL-35 in serum and the tumor microenvironment in CRC patients that correlated with an increase in Tregs. IL-35 expression was assessed using immunofluorescence double staining and was found to be expressed mainly in $\mathrm{CD}^{+}$ $\mathrm{T}$ cells in tumor and tumor adjacent tissues. $\mathrm{CD} 25^{-} \mathrm{CD} 4^{+}$ We found that IL-35 enhanced EBI3 mRNA expression and IL-35 protein levels in T cells and a decrease in Tconv proliferation, suggesting that they were induced to differentiate into iTr35 cells. Interestingly, our experiments in human $\mathrm{CD}^{+} \mathrm{T}$ cells, but not those performed in B cells, showed that rhIL-35 activated the phosphorylation of both STAT1 and STAT3. We speculate that IL-35R might be present in a diverse array of combinations, each of which might lead to different IL-35 activation signals in different species or cell types. Thus, our findings suggest that elevated IL-35 levels induced the generation of $i \operatorname{Tr} 35$ cells, inhibited proliferation in $\mathrm{T}$ effector cells, and activated STAT1 and STAT3 heterodimers in human $\mathrm{CD}^{+} \mathrm{T}$ cells. These results may support the potential therapeutic role of IL-35 in colorectal cancer treatment.

\section{RESULTS}

\section{An increase in Treg cells and IL-35 expression was detected in patients with colorectal cancer}

To determine whether Treg cells and IL-35 are involved in the development of CRC, we first measured the number of circulating Treg cells in PBL using flow cytometry. We then defined the phenotype of the Treg cells as $\mathrm{CD} 4^{+} \mathrm{CD} 25^{+} \mathrm{Foxp}^{+}$. The proportion of Tregs in the HDs ranged from $4.1 \%$ to $10.1 \%$, while it ranged from $3.2 \%$ to $13.8 \%$ in the patients with CRC (Figure 1A and $1 \mathrm{~B}$ ). The frequency of Treg cells was higher in patients with CRC, but there was no significant difference between the groups. Treg cells were markedly increased in tumor tissues and were associated with clinical stage (I-II $24.4 \pm 2.7 \%$ vs III-IV $33.3 \pm 2.8 \%)(P<0.05$, Figure $1 \mathrm{C})$. Interestingly, the proportion of $\mathrm{Th} 17$ cells in the total $\mathrm{CD}^{+} \mathrm{T}$ cells was higher in patients with $\mathrm{CRC}$ than in the HDs (Supplementary Figure S1A and S1B). Combined with the increased Foxp3 mRNA levels in CRC PBMC, EBI3 mRNA expression was upregulated in early stage of CRC (Figure 1D). To some extent, EBI3 expression might not be consistent with Foxp3 levels. Western Blot results showed that the protein expression of EBI3 was higher in cancer $(\mathrm{C})$ than in normal tissues $(\mathrm{N})$ (Figure 1E). High levels of IL-35 were expressed in the CRC serum as measured using ELISA (Figure 1F). IL-35 protein and mRNA expression levels were further investigated in lysate of cancer $(\mathrm{C})$, cancer-adjacent $(\mathrm{A})$ and normal $(\mathrm{N})$ tissues both in early and advanced CRC patients. IL-35 protein was consistent with the increase in EBI3 mRNA expression in tissues (Figure $1 \mathrm{G}$ and $1 \mathrm{H}$ ). Overall, the data show that Treg cells and IL-35 expression were increased in CRC patients.

\section{IL-35 was highly expressed in $\mathrm{CD}^{+} \mathrm{T}$ cells in tumor-adjacent tissues and was associated with tumor metastasis}

We applied immunoprecipitation, immunohistochemistry and immunofluorescence assays to further analyze the expression and localization of heterodimeric cytokine IL-35. Tissue lysis was immunoprecipitated with anti-human IL-12A and detected using anti-human EBI3 antibodies. We found high levels of IL-35 expression in tumors and tumor-adjacent tissues (Figure 2A and Supplementary Figure S1C). IL-35-positive cells were primarily lymphocytes in both tumors and tumor-adjacent tissues (Figure 2B), and IL-35 was especially highly expressed in $\mathrm{CD}^{+} \mathrm{T}$ cells (Figure $2 \mathrm{C}$ ). The staining score for IL35 was higher in adjacent tissues than in the tumors themselves and was associated advanced clinical stage tumors (Figure 2D, $P<0.05$ ). However, higher IL-35 expression was not significantly associated 
Table 1: Correlations with IL-35 expression in tumor and tumor-adjacent tissues

\begin{tabular}{|c|c|c|c|c|c|c|c|c|c|c|c|}
\hline & & Tumor & Adjacent & Gender & Age & $\begin{array}{c}\text { Pathological } \\
\text { grading }\end{array}$ & $\begin{array}{c}\text { Tumor } \\
\text { size }\end{array}$ & T Stage & $\begin{array}{l}\text { Lymphatic } \\
\text { metastasis }\end{array}$ & $\begin{array}{c}\text { Distant } \\
\text { metastasis }\end{array}$ & $\begin{array}{l}\text { TNM } \\
\text { Stage }\end{array}$ \\
\hline \multirow[t]{3}{*}{ Tumor } & $\begin{array}{l}\text { Correlation } \\
\text { Coefficient }\end{array}$ & 1.000 & $.299 * *$ & -.021 & -.209 & .206 & -.064 & .048 & .013 & .028 & .035 \\
\hline & Sig. (2-tailed) & / & .005 & .845 & .052 & .053 & .553 & .660 & .902 & .794 & .748 \\
\hline & $\mathrm{N}$ & 89 & 85 & 89 & 87 & 89 & 87 & 87 & 89 & 88 & 87 \\
\hline \multirow[t]{3}{*}{ Adjacent } & $\begin{array}{l}\text { Correlation } \\
\text { Coefficient }\end{array}$ & $.299 * *$ & 1.000 & .061 & -.010 & .062 & -.139 & -.076 & .110 & $.291 * *$ & .109 \\
\hline & Sig. (2-tailed) & .005 & / & .575 & .929 & .572 & .207 & .487 & .311 & .007 & .322 \\
\hline & $\mathrm{N}$ & 85 & 86 & 86 & 84 & 86 & 84 & 85 & 86 & 85 & 85 \\
\hline
\end{tabular}

with reduced overall survival in patients at followups (Figure 2E, $P>0.05$ ). While, its expression in adjacent tissues was correlated with distant metastasis $(P=0.007)$ (Table 2). As expected, IL-35 was expressed in CRC, and it was significantly associated with tumor metastasis.

\section{Reconstituted human IL-35 inhibited CD4 ${ }^{+} \mathrm{T}$ cell proliferation}

In previous in vitro studies, the suppression of IL-35 on $\mathrm{T}$ cell proliferation was reported to be dependent on IL-35 itself but not on IL-10 or TGF- $\beta$ in mice. To

A

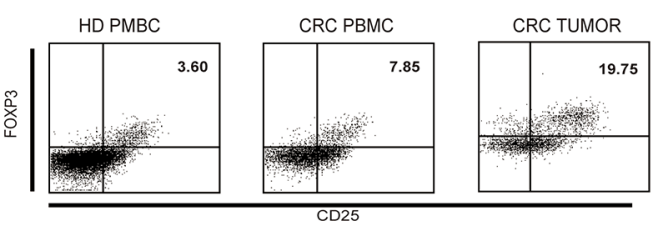

B

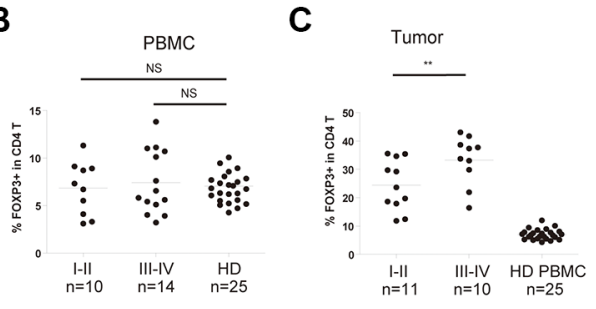

D

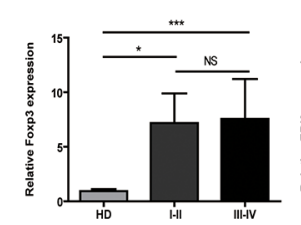

$\mathbf{F}$

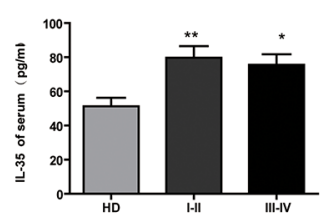

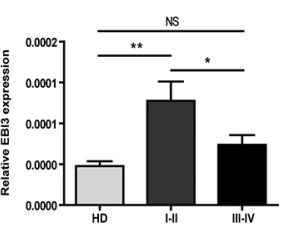

G

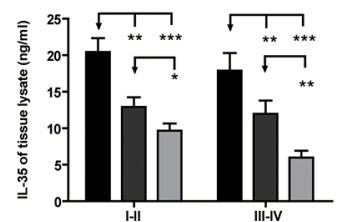

E

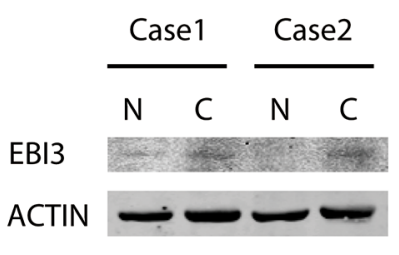

H

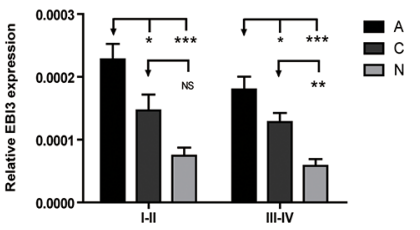

Figure 1: Increased Treg numbers and IL-35 levels in patients with CRC. (A) Representative flow cytometric (FCM) dot plots showing Foxp3 and CD25 double-labeled CD4 T cells both in healthy donors (HD) and CRC patients. (B and C) Significantly increased proportions of Treg cells in CRC patients in early and advanced clinical stages compared to the proportions in healthy donors. (D) The mRNA expression levels of Treg-related transcription factors and the IL-35 subunit EBI3 in PBMCs. (E) Immunoblotting analyzed the EBI3 expression in normal $(\mathrm{N})$ and cancer $(\mathrm{C})$ tissue of patients with CRC. (F) Serum IL-35 concentrations of HD and CRC were detected by ELISA. (G) IL-35 concentrations in lysate supernatant of colorectal cancer (Dark Grey, C), adjacent (Black, A) and normal mucosal tissues (Light grey, N) were detected. (H) The mRNA expression levels of the IL-35 subunit EBI3 in PBMCs. Data represent the mean \pm SEM. ${ }^{*} p<0.05,{ }^{* *} p<0.01$, and $* * * p<0.001$ compared to the HD group. 
determine the role of IL-35 in immunosuppression, we treated CFSE-labeled $\mathrm{CD} 4{ }^{+} \mathrm{CD} 25^{-} \mathrm{T}$ cells obtained from $\mathrm{HD}$ with a series of concentrations of rhIL-35 ranging from $0 \mathrm{ng} / \mathrm{ml}$ to $200 \mathrm{ng} / \mathrm{ml}$ for 5 days and then detected cell proliferation using FACS. IL-35 markedly inhibited $\mathrm{T}$ cell proliferation in a dose-dependent manner (Figure 3A). Studies have reported that IL35 is primarily produced by Treg cells and that IL-35 executes the functions of these cells. Blocking IL-35 using neutralizing antibodies partially eliminated the immunosuppression of Tregs and restored $\mathrm{CD} 4^{+} \mathrm{CD} 25^{-}$ $\mathrm{T}$ cell proliferation (Figure $3 \mathrm{~B}$ ). These data indicated the IL-35 involved in tumor immunotolerance.

\section{IL-35 activated the STAT1/STAT3 signaling pathway in human $T$ cells}

Studies in mice have reported that IL-35 activates STAT1 and STAT4 heterodimers, or either STAT1 or STAT4 homodimers in T cells (21). While, IL-35 activates STAT3 in B cells (22). To analyze the IL-35 signaling pathway in human $\mathrm{T}$ cells, we analyzed a series of transcription factors known to be related to the IL-12 family in $\mathrm{CD} 4^{+} \mathrm{CD} 25^{-}$ $\mathrm{T}$ cells following stimulation with or without IL-35 compared with Tregs. Immunoblotting results showed that IL-35 promoted the phosphorylation of STAT1 and STAT3 and activated upstream phospho JAK1 and TYK2. But STAT4 activation was not detected for both long term and transient IL-35 treatment (Figure 4A). IL-35 significantly increased the phosphorylation of STAT1, STAT3 and JAK1 in a time-dependent manner in freshly isolated pan-T cells (Figure 4B). The increased phosphorylation of STAT1, STAT3 and JAK1 was reduced when IL-35 neutralizing antibodies were added (Figure 4C). Because different STATx were activated in human T cells, we also purified B cells to perform the same experiments. The results showed that IL-35 did not increase the total and phosphorylated levels of STAT1 and STAT3 in human B cells (Figure 4D). To verify the STAT1 and STAT3 activation, PBMCs treated with rhIL-35 together with fludarabine (STAT1 inhibitor,
A

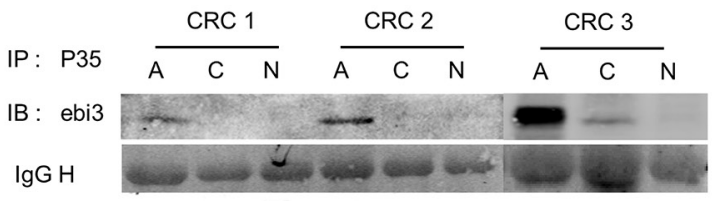

B

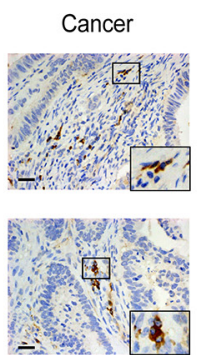

C

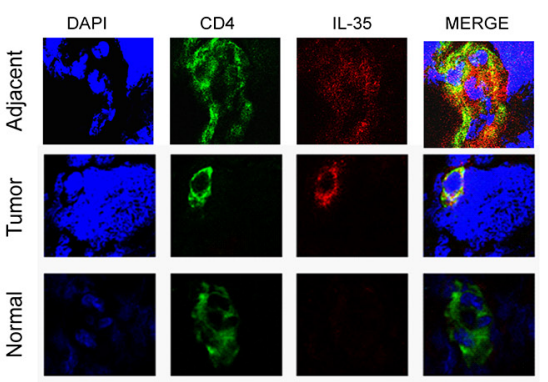

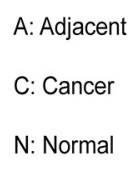
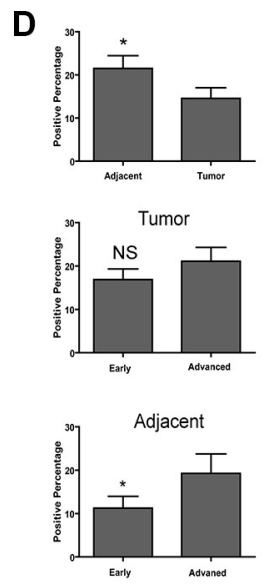

E

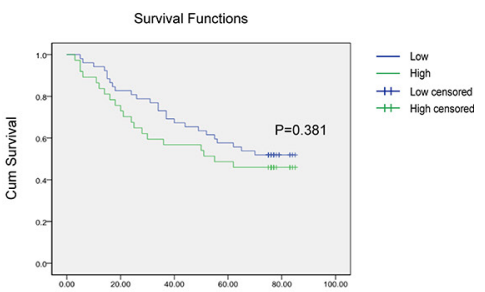

Figure 2: IL-35 is expressed in $\mathrm{CD4}^{+} \mathrm{T}$ cells in tumor-adjacent tissues and is associated with tumor metastasis. (A) Colorectal cancer (C), adjacent (A) and normal mucosal tissues (N) (200 mg) lysis supernatants were immunoprecipitated using antihuman IL-12A antibodies and then coupled to protein A/G-agarose beads. Proteins were resolved using SDS-PAGE, and the blots were then probed using monoclonal anti-human EBI3 antibodies. (B) Representative images of cells labeled for the cytoplasmic marker IL-35 using immunohistochemistry. IL-35 was detected using mouse anti-human IL-35 monoclonal antibodies that were diluted 1:300 as the primary antibody in tumor, tumor-adjacent and mucosal tissues from the same individual. Scale bars, $100 \mu \mathrm{m}$. (C) Representative images obtained using confocal microscopy showed CD4 (green) and IL-35 (red) expression in frozen tissue samples. Nuclei were stained with DAPI (blue). (D) The total scores were calculated as the intensity of staining for IL-35 plus the percentage of positive cells in tumor and tumor-adjacent tissues in patients with early and advanced stages. (E) A Kaplan-Meier curve was plotted and used to analyze overall survival in CRC patients based on the total scores (see above): low expression group (total score $<1$ ) and high expression (total score $\geq 1$ ) groups. Data represent the mean \pm SEM. $* p<0.05$ 
$10 \mu \mathrm{mol} / \mathrm{ml}$ ) or cryptotanshinone (STAT3 inhibitor, $20 \mu \mathrm{mol} / \mathrm{ml}$ ) were examined STAT1 and STAT3 phosphorylation. The inhibitor treatment could partially downregulated specific phosphorylation (Figure 4E). Collectively, these data suggested that IL-35 activated STAT1 and STAT3 in human T cells.

\section{IL-35 induced positive feedback promotes increased IL-35 production}

IL-35 has been shown to induce the conversion conventional $\mathrm{T}$ cells (Tconv) into IL-35-producing Treg (iTr35) cells, especially in mice. We first purified $\mathrm{CD}^{+} \mathrm{T}$ cells from 10 healthy individuals, and cells were treated with $200 \mathrm{ng} / \mathrm{ml} \mathrm{rhIL-35}$ which promoted the mRNA expression of Foxp3 and IL-35 (EBI3 and P35) (Figure 5A). We used purified $\mathrm{CD} 4^{+} \mathrm{CD} 25^{-} \mathrm{T}$ effectors $\left(\mathrm{T}_{\text {eff }}\right), \mathrm{CD}^{+} \mathrm{CD} 25^{+}$Treg cells as the positive control, and observed that the expression of the EBI3 and P35 mRNAs was increased more than the expression of Foxp3 in CD $4^{+} \mathrm{CD} 25^{-} \mathrm{T}$ cells (Figure $5 \mathrm{~B}$ ). Also, IL-10 and TGF- $\beta$ mRNA was less expressed in $\mathrm{CD} 4^{+} \mathrm{CD} 25^{-} \mathrm{T}$ cells than in Tregs (Supplementary Figure S2A). Immunoprecipitation assays were performed to analyze culture supernatants to confirm the production of IL-35 in $\mathrm{CD}^{+} \mathrm{T}$ cells from HD and CRC patients. Results of gray value showed that $\mathrm{CD}^{+} \mathrm{T}$ cells from $\mathrm{CRC}$ patients produced less IL-35 than HD, but there was no significant difference between two groups (Figure 5C). To determine whether Treg cell were capable of inducing IL-35-producing $\mathrm{CD}^{+} \mathrm{CD} 25^{-} \mathrm{T}$ cells, CD4 ${ }^{+} \mathrm{CD} 25^{-} \mathrm{T}_{\text {eff }}$ from $\mathrm{HD}$ was co-cultured with autologous Treg for 5 days. After co-cultured with Tregs, $\mathrm{T}_{\text {eff }}$ markedly increased the expression of Foxp3, EBI3 and P35 mRNAs (Figure 5D and Supplementary Figure S2B). While, IL-35 blockade repressed the expression of EBI3 and STAT1 mRNAs in $\mathrm{HD} \mathrm{CD} 4^{+} \mathrm{CD} 25^{-} \mathrm{T}$ cell co-culture systems (Figure $5 \mathrm{E}$ ). When $\mathrm{CD}^{+} \mathrm{CD} 25^{-} \mathrm{T}_{\text {eff }}$ from $\mathrm{CRC}$ patients were cocultured with autologous Treg, consistent results could be observed (Figure 6A). To clarify whether Tregs obtained from $\mathrm{CRC}$ patients was potential to increase remarkably the expression of Foxp3, EBI3 and P35 mRNAs in $\mathrm{T}_{\text {eff }}$, HD $\mathrm{T}_{\text {eff }}$ were incubated with Tregs from HD and CRC using a transwell system. CRC Treg itself expressed higher mRNAs and induced IL-35 related mRNAs expression in HD $\mathrm{T}_{\text {eff }}$, especially STAT1 and STAT3 (Figure 6B).

To determine whether IL-35 directly participates in the production of IL-35, EBI3 promoter-driven luciferase reporter plasmids and mock plasmids were constructed and transferred into isolated PBMC using electroporation. EBI3 promoter-driven luciferase activity was higher after IL-35 stimulation than the activity induced in cells expressing the mock plasmid (Figure 6C and 6D). Thus, our study indicates that high IL-35 levels in colorectal cancer promotes the increased production of IL-35 via STAT1 and STAT3 and results in

A

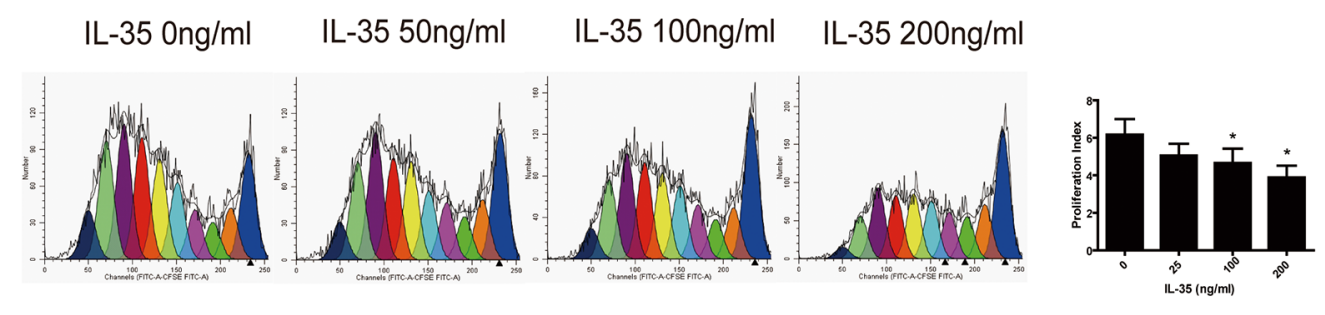

B
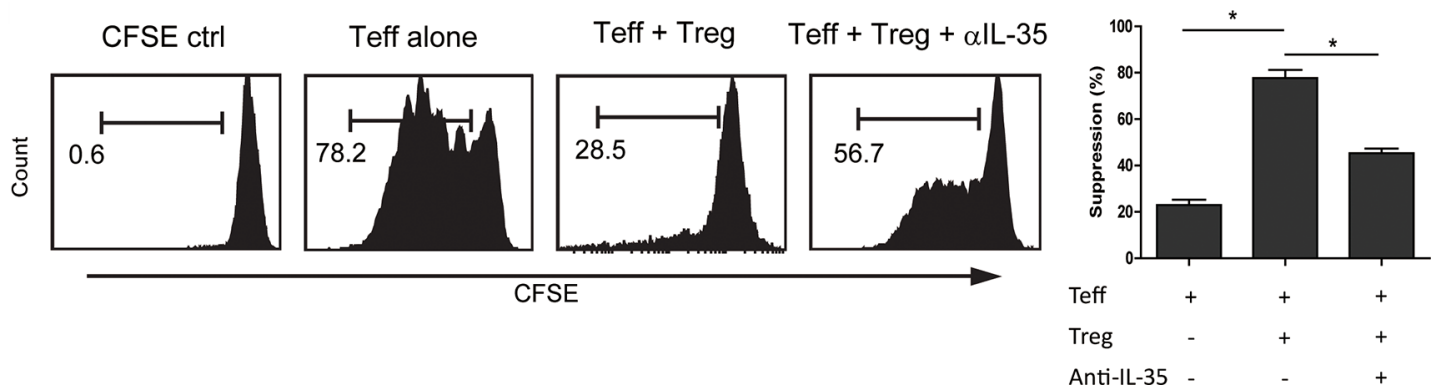

Figure 3: IL-35 suppressed CD4 ${ }^{+}$T cell proliferation. (A) CFSE-labeled $\mathrm{CD}^{+} \mathrm{CD} 25^{-} \mathrm{T}\left(1 \times 10^{5}\right.$ per well $)$ cells obtained from $\mathrm{HDs}$ were incubated in a series of concentrations of rhIL-35 for 5 days and analyzed to determine the cell proliferation index using FACS and the appropriate software (ModFit LT; BD). (B) Using a transwell culture system $(0.4 \mu \mathrm{m})$, as shown, CFSE-labeled CD4 ${ }^{+} \mathrm{CD} 25^{-} \mathrm{T}$ cells $\left(1 \times 10^{5}\right.$ per well $)$ rom HDs were co-cultured with autologous $\mathrm{CD}^{+} \mathrm{CD} 25^{+} \mathrm{T}$ cells $\left(5 \times 10^{4}\right.$ per well $)$ in the presence of IL-35-neutralizing antibodies. Cell proliferation was analyzed using FACS. The data shown are representative of three independent experiments. The results are shown as the mean \pm SEM. $* p<0.05$. 
the suppression of $\mathrm{T}$ cell proliferation, leading to tumor immunotolerance.

\section{DISCUSSION}

Colorectal cancer is a major public health problem in China, where it is currently the second leading cause of cancer death $[22,23]$. Tumor immunity and inflammation are regarded as important to carcinogenesis and development in colorectal carcinomas, but the underlying mechanisms of its growth are not yet fully understood. A major question is whether the host's immune system has constitutive house-keeping anti-inflammatory defenses that can counteract the onset of inflammation or whether the host needs to generate and secrete such antiinflammatory cytokines during inflammation de novo.
A

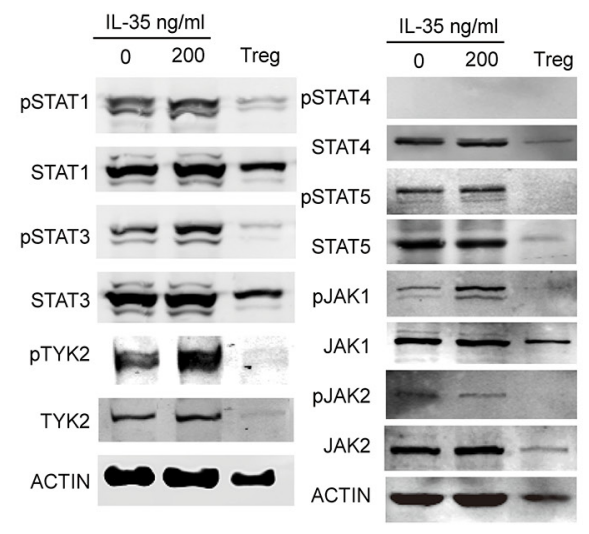

C

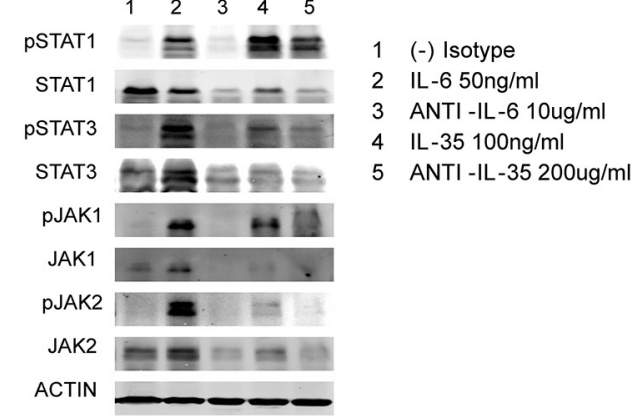

E

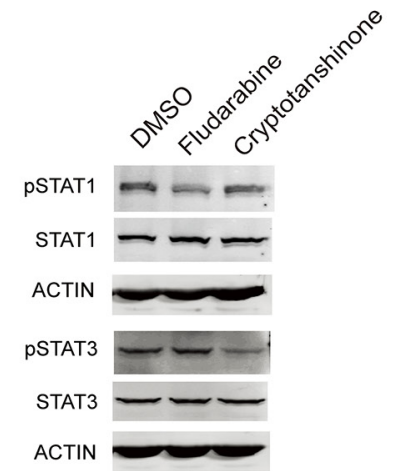

B

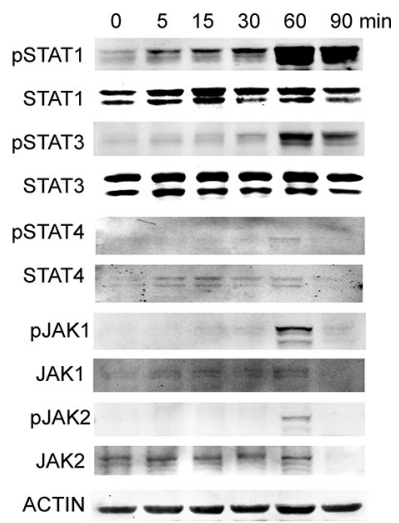

D

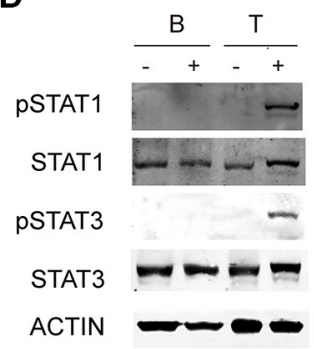

Figure 4: The signaling pathway activated in IL-35-stimulated T cells. (A) $\mathrm{CD} 4^{+} \mathrm{CD} 25^{-} \mathrm{T}$ and $\mathrm{CD} 4^{+} \mathrm{CD} 25^{+}$Treg $\left(1 \times 10^{5}\right.$ per well) cells purified from HDs were activated using $\alpha$ CD3/CD28 with $200 \mathrm{ng} / \mathrm{ml}$ rhIL-35 or PBS. Total protein was extracted from cells collected on day 5 and analyzed to determine the levels of IL-12 family-related transcription factors using western blot analysis. (B) The phosphorylated and total levels of STAT1, STAT3, JAK1, and JAK2 were examined using immunoblotting assays immediately in $200 \mathrm{ng} / \mathrm{ml} \mathrm{rhIL-35-activated} \mathrm{freshly} \mathrm{isolated} \mathrm{Pan} \mathrm{T} \mathrm{cells.} \mathrm{(C)} \mathrm{An} \mathrm{IL-35} \mathrm{blockade} \mathrm{was} \mathrm{applied} \mathrm{while} \mathrm{the} \mathrm{cells} \mathrm{were} \mathrm{activated} \mathrm{with} \mathrm{rhIL-35,} \mathrm{as}$ described. The phosphorylated and total expression levels of STAT1, STAT3, JAK1, and JAK2 were examined after 60 min. IL-6 blockade was used as the positive control. (D) The phosphorylated and total expression levels of STAT1 and STAT3 were examined in purified B and T cells using immunoblotting assays after they were rhIL-35-activated. (E) The phosphorylated and total expression levels of STAT1 and STAT3 were examined in PBMCs treated with fludarabine (STAT1 inhibitor, $10 \mu \mathrm{mol} / \mathrm{ml}$ ) and cryptotanshinone (STAT3 inhibitor, $20 \mu \mathrm{mol} / \mathrm{ml}$ ) and rhIL-35 together for $1 \mathrm{hr}$. The data shown are representative of three independent experiments. 
IL-35 is a newly reported anti-inflammatory cytokine upregulated against the inflammation response, but it is not constitutively expressed as a housekeeping cytokine [24]. IL-35, like IL-12 and IL-27, is a heterodimeric cytokine composed of P35 and EBI3. IL-12 is composed of P35 and p40, and IL-27 is composed of p28 and EBI3 [25, 26]. Although these three cytokines share subunits, their biological functions are very different. IL-12 is a pro-inflammatory regulator of Th1 responses, IL-27 has biphasic functions in inflammation, and IL-35 is inhibitory [27, 28]. EBI3 subunit was considered to be more responsible to its biological functions. Studies in mice have demonstrated that IL-35 plays key roles in autoimmune diseases [11, 18], allergenic diseases [29, 30]

A
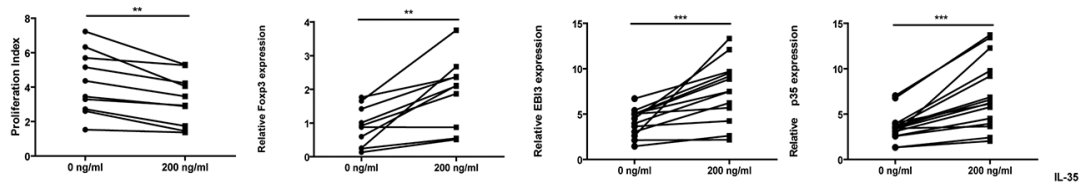

B
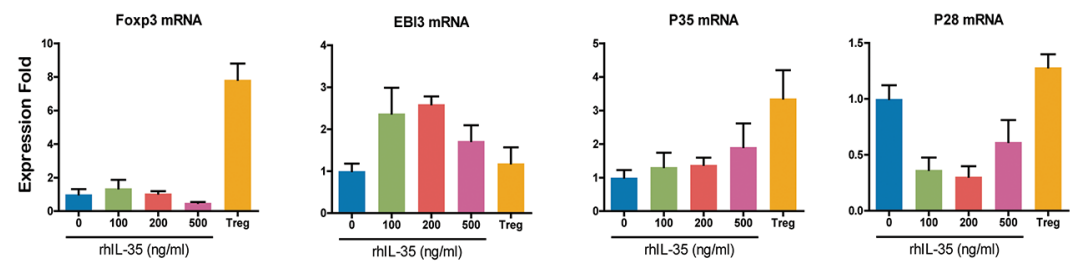

C
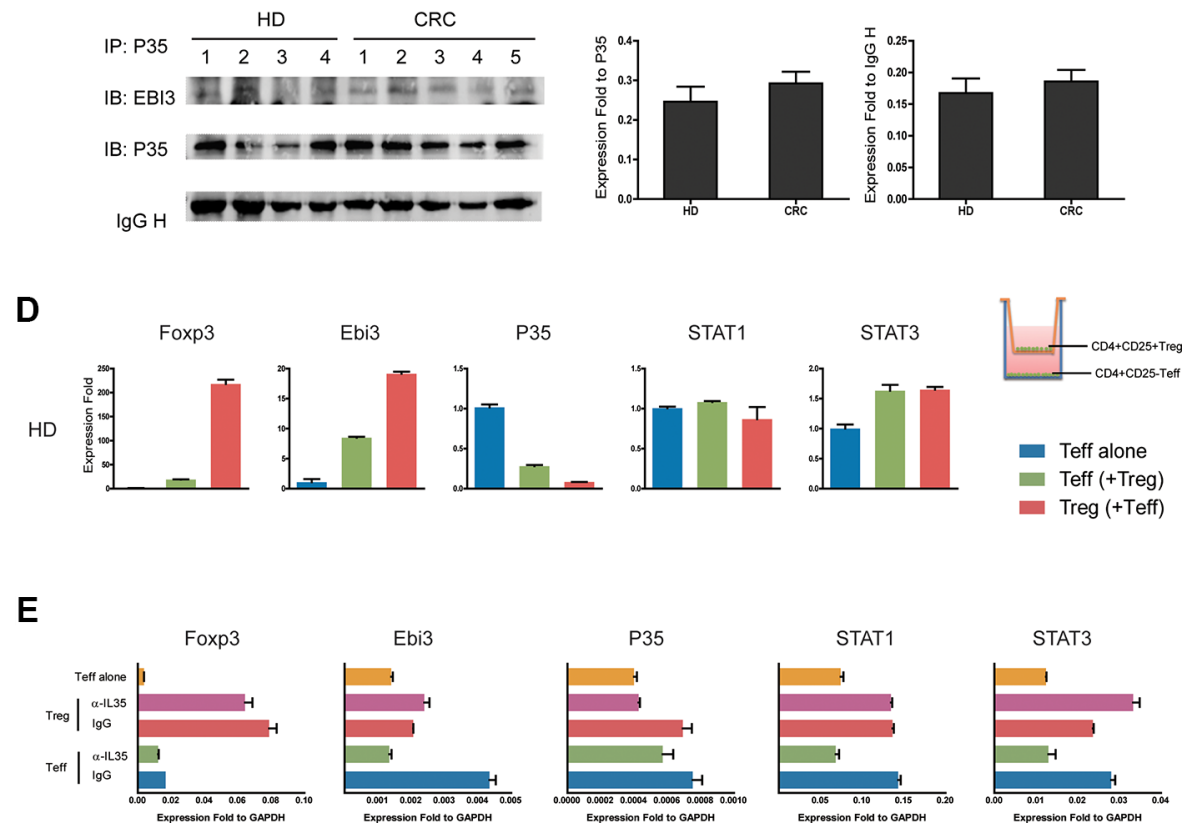

Figure 5: IL-35 production was increased through positive feedback. $(A) \mathrm{CD} 4^{+} \mathrm{CD} 25^{-} \mathrm{T}$ cells $\left(1 \times 10^{5}\right.$ per well $)$ from $\mathrm{HDs}$ $(N=10)$ were incubated with rhIL-35 at a final concentration of $200 \mathrm{ng} / \mathrm{ml}$. Cell proliferation and the expression of Foxp3, EBI3, and P35 mRNAs were observed on day 5. (B) $\mathrm{CD} 4^{+} \mathrm{CD} 25^{-} \mathrm{T}$ cells $\left(1 \times 10^{5}\right.$ per well $)$ obtained from HDs were incubated in a series of concentrations of rhIL-35 for 5days, and the expression levels of Foxp3, EBI3, P35 and the IL-12 cytokine family-related subunit P28 mRNAs were analyzed. (C) IL-35 expression was analyzed in the culture supernatants of $\mathrm{CD} 4^{+} \mathrm{CD} 25^{-} \mathrm{T}$ cells stimulated with rhIL-35, confirmed following immunoprecipitation with anti-human IL-12A (P35) antibodies, and resolved using SDS-PAGE. The blots were then probed with monoclonal anti-human EBI3 and P35 antibodies. Scan image software detected the gray values of each EBI3, P35 and IgH protein bands. The values of EBI3 were normalized to $\mathrm{P} 35$ and IgH, respectively. (D) $\mathrm{CD}^{+} \mathrm{CD} 25$ - T cells $\left(1 \times 10^{5}\right.$ per well $)$ obtained from HDs were co-cultured with autologous $\mathrm{CD} 4^{+} \mathrm{CD} 25^{+} \mathrm{T}$ cells $\left(5 \times 10^{4}\right.$ per well $)$ in transwell culture system $(0.4 \mu \mathrm{m})$ for 5 days. The mRNA expression levels of Foxp3, EBI3 and P35 were observed. Blue bar, $\mathrm{HD} \mathrm{T}_{\text {eff }}$ control which co-cultured with autologous $\mathrm{T}_{\text {eff }}$; green bar, $\mathrm{HD} \mathrm{T}_{\text {eff }}$ which co-cultured with Treg; red bar, HD Treg which co-cultured with $\mathrm{T}_{\text {eff }}$ (E) IL-35-neutralizing antibodies were added to the coculture systems of $\mathrm{CD} 4^{+} \mathrm{CD} 25^{-} \mathrm{T}\left(1 \times 10^{5}\right.$ per well $)$ cells and autologous $\mathrm{CD} 4^{+} \mathrm{CD} 25^{+} \mathrm{T}$ cells $\left(5 \times 10^{4}\right.$ per well $)$ that were obtained from HDs. After 5 days, the mRNA expression levels of Foxp3, EBI3, P35, STAT1 and STAT3 were observed using Q-PCR. The data shown are representative of three independent experiments. The results are shown as the mean \pm SEM. $* p<0.05$. 
and other diseases, such as infection. However, the role of IL-35 in humans requires further study.

Human IL-35 expression has been reported in chronic hepatitis B virus-infected patients [31], normal pregnancies [32], sepsis [33], and rheumatoid arthritis [34]. In support of a mathematical modeling analysis that reported a correlation between IL-35 and tumors [16], we demonstrate that elevated IL-35 level in CRC patients is coincident with an increase in Treg cells and it was mainly expressed in $\mathrm{CD}^{+} \mathrm{T}$ cells in human colorectal cancer and adjacent tissues. Its expression in CRC tumor-adjacent tissues is significantly associated with tumor metastasis.

A

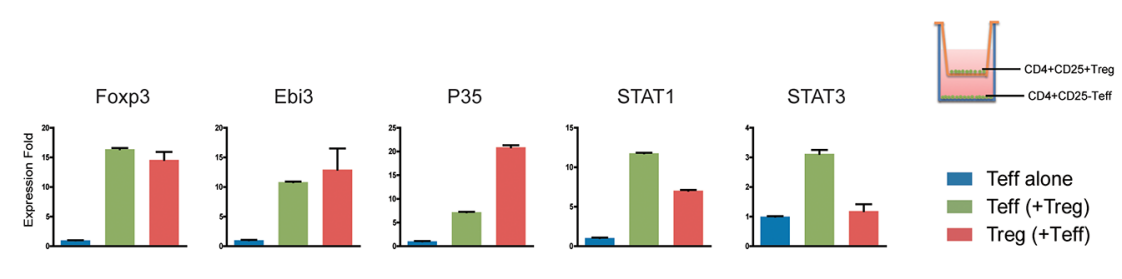

B

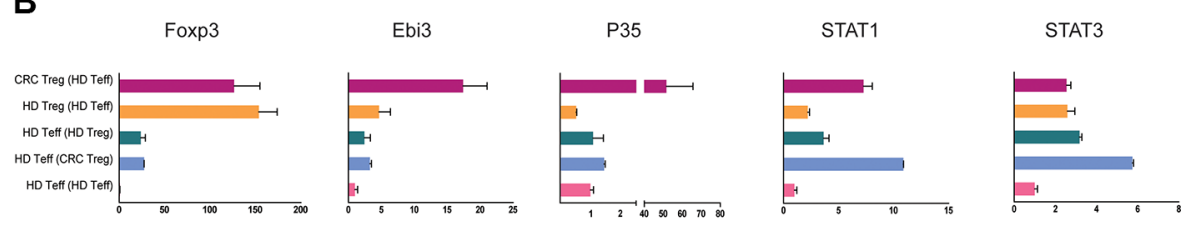

C

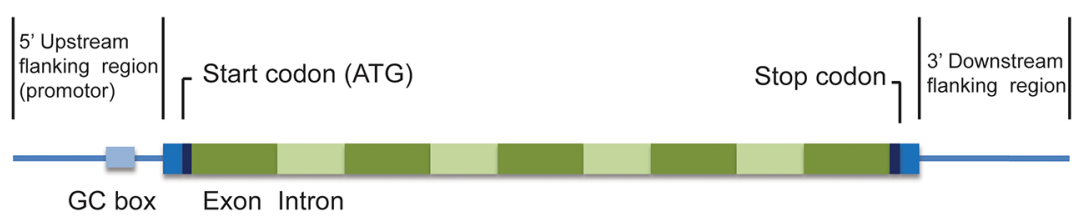

D

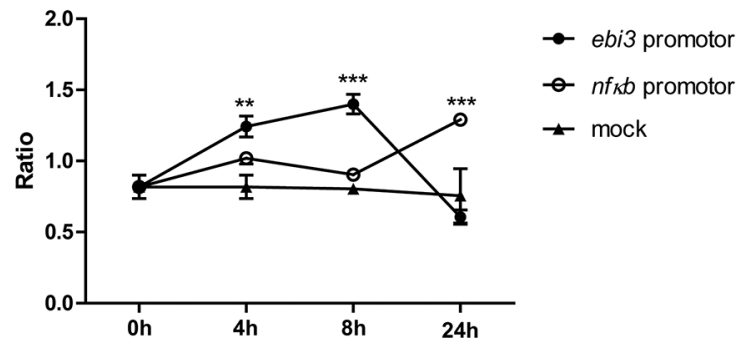

Figure 6: The transcriptional activity of the EBI3 promoter was induced by stimulation with IL-35. (A) CD4+CD25 $\mathrm{T}_{\text {eff }}$ cells $\left(1 \times 10^{5}\right.$ per well) obtained from CRC patients were co-cultured with autologous $\mathrm{CD} 4^{+} \mathrm{CD} 25^{+}$Treg cells $\left(5 \times 10^{4}\right.$ per well $)$ in transwell culture system $(0.4 \mu \mathrm{m})$ for 5 days. The mRNA expression levels of Foxp3, EBI3, and P35 were observed. Blue bar, HD Teff control which co-cultured with autologous $\mathrm{T}_{\mathrm{eff}}$; green bar, HD Teff which co-cultured with Treg; red bar, HD Treg which co-cultured with Teff. (B) $\mathrm{CD}^{+} \mathrm{CD} 25^{-}$Teff cells $\left(1 \times 10^{5}\right.$ per well $)$ obtained from $\mathrm{HD}$ were co-cultured with autologous $\mathrm{CD} 4^{+} \mathrm{CD} 25^{+}$Treg cells or allogeneic Treg cells from CRC $\left(5 \times 10^{4}\right.$ per well $)$ in transwell culture system $(0.4 \mu \mathrm{m})$ for 5 days. Series mRNA expression levels were observed. Violet, $C R C$ Treg which co-cultured with allogeneic $T_{\text {eff }}$ orange, $\mathrm{HD}$ Treg which co-cultured with autologous $\mathrm{T}_{\text {eff: }}$ dark green, $\mathrm{HD} \mathrm{T}_{\text {eff }}$ which co-cultured with autologous Treg; lavender, $\mathrm{HD} \mathrm{T}_{\text {eff }}$ which co-cultured with allogeneic $\mathrm{T}_{\text {eff }} ;$ pink, $\mathrm{HD} \mathrm{T}_{\text {eff }}$ control. (C) Schematic diagram showing the structure of the EBI3 gene. (D) An EBI3 promoter-containing fragment (bp -450 to +8 UTR) was ligated into the promoterless luciferase $(l u c+)$ vector pGL3 basic (Promega). The vectors containing the EBI3 promoter and the NF-kB promoter and the mock plasmids were transferred into human pan T cells using electroporation. After 4, 8 and 24 hours of incubation with $200 \mathrm{ng} / \mathrm{ml} \mathrm{IL}-35$, the transcriptional activity of each gene promoter was determined. The data shown are representative of the mean $\pm \operatorname{SEM}$. $* * p<0.01, * * * p<0.001$ 
IL-35 as a potent anti-inflammatory cytokine is reported for the suppressive activity of regulatory $\mathrm{T}$ cells especially in mice. Our results also shown that reconstituted human IL-35 suppressed proliferation of $\mathrm{CD} 4^{+} \mathrm{CD} 25^{-} \mathrm{T}$ cells, and this suppression could be restored partially using IL-35-neutralizing antibodies. However, we did not observe the considerable rate of inhibition that has been shown in vitro in Tregs or in mice studies. It has also been reported that IL-35 specifically attenuates the production of IL-17 in collagen-induced arthritis [11], allergic airways disease in mice [30] or infection [35]. Interestingly, the proportion of Th17 cells in the total population of $\mathrm{CD}^{+} \mathrm{T}$ cells in patients with $\mathrm{CRC}$ was higher than their proportion in healthy individuals (Supplementary Figure S1A and S1B). Thus, the function of IL-35 in human diseases needs further investigation to determine the mechanisms of its immunoregulation in humans.

Studies have revealed the role of IL-35 in the conversion of murine and human $\mathrm{CD} 4^{+} \mathrm{CD} 25^{-} \mathrm{T}$ cells into IL-35-induced Treg (iTr35) cells $[4,36]$. In this work, results showed rhIL-35 could induce the expression of EBI3 and P35 mRNAs, but not p28 or p40 mRNAs, in $\mathrm{CD} 4^{+} \mathrm{CD} 25^{-} \mathrm{T}$ cells. It is worth noting that endogenous IL-35 that was derived specifically from CRC patients' Tregs was capable of inducing a further increase in IL-35.

IL-35, by binding to its receptor, recruited and activated of specific members of the STAT family of transcription factors to mediate their biological activities $[37,38]$. The IL-35 receptor in mice has been reported to be composed of IL-12R $\beta 2$ subunits (share with IL-12 receptors) and gp 130 (share with IL-6 receptors) on T cells [20], or subunit IL-27R $\alpha$ (share with IL-27 receptors) on $\mathrm{B}$ cells [21]. These differences may explain the diversity of downstream STAT-activating activities that have been observed in T and B cells in mice. In this study, we demonstrated that IL-35 treatment activated STAT1 and STAT3 in human $\mathrm{CD}^{+} \mathrm{T}$ cells both during incubation and following temporary stimulation. IL-35 did not activate STAT1 and STAT3 in B cells following temporary stimulation. We speculate that IL-35R is not constitutively expressed on human B cells, while is expressed on $\mathrm{CD}^{+}$ $\mathrm{T}$ cells in humans. This suggests the possibility that there is diversity in the composition of IL-35 receptors on different cell types or in different species. Meanwhile, the observed differences in the activated signaling pathways indicate that human results may not be reproduced in mice. Thus, when using a genetic deficiency approach to study the role of IL-35 in mice, it might be difficult to obtain consistent data in human diseases. To determine whether IL-35 directly promoted IL-35 production, we constructed an EBI3 promoter-driven luciferase reporter plasmid. After stimulation with IL-35, EBI3 promoter-driven luciferase activity was higher than that of the mock plasmid. EBI3 transcription was reported induced by TLR signaling via
NF- $\kappa \mathrm{B}$ activation [39]. We used NF- $\kappa \mathrm{B}$ promoter-driven luciferase reporter as positive control. Results suggested the indirect links between IL-35 signaling and NF- $\mathrm{KB}$ activation.

Taken together, this study demonstrates that elevated IL-35 expression in CRC, especially in tumor-adjacent tissues is significantly associated with tumor metastasis. IL-35 inhibited $\mathrm{CD} 4{ }^{+} \mathrm{CD} 25^{-} \mathrm{T}$ effector cell proliferation in vitro, which could be restored partially by applying IL-35-neutralizing antibodies. IL-35 Treatment activated the phosphorylation of STAT1 and STAT3 in human $\mathrm{CD}^{+} \mathrm{T}$ cells. IL-35 induced positive feedback to promote IL-35 production, and this process is involved in tumor immunity. Tregs obtained from colorectal cancer patients were more capable of inducing EBI3 and P35 expression than those obtained from healthy individuals. Thus, our study indicates that the high level of IL-35 observed in colorectal cancers promotes its own production via STAT1 and STAT3 to suppress T cell proliferation during tumor immunity. This suggests potential immunoregulatory therapeutic strategies involving IL-35 for the treatment of CRC.

\section{MATERIALS AND METHODS}

\section{Subjects}

Fresh blood and tumor tissues were obtained from 125 sporadic CRC patients who underwent radical resection from March, 2012 to February, 2014 in Xinhua Hospital, Shanghai Jiao Tong University School of Medicine. The patients were histopathologically confirmed to have colorectal cancer. The clinical data and outcomes were obtained from clinical records and pathological reports. All patient characteristics are described in Table 1. We excluded the cases that were treated with radiation, chemotherapy, or immunotherapy before surgery. Patients who had any other history of cancer, autoimmune disease, inflammatory bowel disease, or infectious disease were also excluded. To stage tumors, the sixth edition of the AJCC Cancer Staging Manual was applied (TNM). Patients were divided into two subgroups: TNM I-II and TNM III-VI. The study was approved by the Ethical Committee of Xinhua Hospital affiliated with the Jiao tong University School of medicine. Written informed consent was obtained from all patients, and the study conformed to the principles of the Declaration of Helsinki.

\section{Blood sampling and flow cytometric analysis}

All blood samples used for this study were collected at the time of admission to the department of general surgery. PBMCs were freshly isolated from $4 \mathrm{ml}$ of heparinized blood using Ficoll density gradient centrifugation. Lymphocytes were re-suspended in 
Table 2: Clinical characteristics of CRC patients

\begin{tabular}{|c|c|c|c|c|c|c|}
\hline \multirow[t]{3}{*}{ Characteristics } & \multicolumn{3}{|c|}{ Colon Cancer N (\%) } & \multicolumn{3}{|c|}{ Rectal Cancer $N(\%)$} \\
\hline & \multicolumn{2}{|c|}{ STAGE } & \multirow[t]{2}{*}{$P$} & \multicolumn{2}{|c|}{ STAGE } & \multirow[t]{2}{*}{$P$} \\
\hline & I-II & III-IV & & I-II & III-IV & \\
\hline $\mathrm{N}$ & 38 & 39 & & 22 & 26 & \\
\hline \multicolumn{7}{|l|}{ Age } \\
\hline$\leq 60$ & $13(34.21)$ & $12(30.77)$ & 0.81 & $7(31.82)$ & $11(42.31)$ & 0.555 \\
\hline$<60$ & $25(65.79)$ & $27(69.23)$ & & $15(68.18)$ & $15(57.69)$ & \\
\hline \multicolumn{7}{|l|}{ Gender } \\
\hline Male & $13(34.21)$ & $20(51.28)$ & 0.169 & $13(59.09)$ & $14(53.85)$ & 0.776 \\
\hline Female & $25(65.79)$ & $19(48.72)$ & & $9(40.91)$ & $12(46.15)$ & \\
\hline \multicolumn{7}{|l|}{ Location } \\
\hline Ascending colon & $14(36.84)$ & $15(38.46)$ & 0.442 & NA & NA & \\
\hline Transverse colon & $3(7.89)$ & $7(17.95)$ & & NA & NA & \\
\hline Descending colon & $9(23.68)$ & $4(10.26)$ & & NA & NA & \\
\hline Ileocecal region & $2(5.26)$ & $3(7.70)$ & & NA & NA & \\
\hline Sigmoid colon & $10(26.32)$ & $10(25.64)$ & & NA & NA & \\
\hline Rectum & NA & NA & & $22(100)$ & $26(100)$ & NA \\
\hline \multicolumn{7}{|l|}{ Pathological type } \\
\hline Tubular adenocarcinoma & $31(81.58)$ & $28(71.80)$ & 0.728 & $16(72.73)$ & $21(80.77)$ & 0.544 \\
\hline Mucinous Adenocarcinoma & $2(5.26)$ & $4(10.26)$ & & $0(0)$ & $0(0)$ & \\
\hline Papillary Adenocarcinoma & $2(5.26)$ & $2(5.13)$ & & $2(9.09)$ & $3(11.54)$ & \\
\hline Unknown & $3(7.89)$ & $5(12.82)$ & & $4(18.18)$ & $2(7.69)$ & \\
\hline \multicolumn{7}{|l|}{ Differentiation } \\
\hline Poorly differentiated & $2(5.26)$ & $6(15.38)$ & 0.345 & $2(9.09)$ & $2(7.69)$ & 0.281 \\
\hline Moderately Differentiated & $34(89.47)$ & $31(79.49)$ & & $18(81.82)$ & $24(92.31)$ & \\
\hline Well differentiated & $2(5.26)$ & $2(5.13)$ & & $2(9.09)$ & $0(0)$ & \\
\hline
\end{tabular}

PBS supplemented with $2 \%$ bovine serum albumin at a concentration of $1 \times 10^{6} \mathrm{cells} / \mathrm{ml}$. Cell surface marker analysis was performed using four or five color flow cytometric analysis. Fluorochrome-labeled mouse antihuman monoclonal antibodies against CD3-PC7, CD4PerCP, and CD25-APC were purchased from Beckman Coulter. Foxp3-Ax488 and IgG2a-FITC (eBioscience, CA, USA) antibodies were used in combination with appropriate isotype controls to identify positive and negative cell populations. For double staining of IL-17 and Foxp3, PBMCs were isolated using Ficoll density gradient separation and stimulated with PMA $(50 \mathrm{ng} / \mathrm{ml})$ and ionomycin $(1 \mathrm{mg} / \mathrm{ml})$ in the presence of Golgi-Stop reagent for 4-6 h. First, extracellular labels were used, including specific Abs against human CD3, CD4, and CD25. The cells were then fixed and permeabilized with Perm/Fix solution and stained using anti-IL-17A (intracellular) and anti-Foxp3 (intranuclear) antibodies or control isotype antibodies for $30 \mathrm{~min}$ on ice. Multicolor FACS analysis was performed using a BD FACS Aria flow cytometer (BD).

\section{Real-time PCR}

Total RNA was isolated using Qiagen reagent. Then, first-strand cDNA was synthesized using a Sensiscript RT Kit (Takara) according to the manufacturer's instructions. Real-time RT-PCR was performed as previously described [40]. Data were collected and quantitatively analyzed, and the human GAPDH gene was used as an endogenous control for sample normalization. The following primers were used to assess gene expression: Foxp3, 5'-CTACGCCACGCTCATCCGCTGG-3' (forward) and 5'-GTAGGGTTGGAACACCTGCTGGG-3' (reverse); EBI3， 5'-CTTCGTGCCTTTCATAAC-3' (forward) and 5'-GCTCCCTGACGCTTGT-3' (reverse); P35, 5'-CTCCTGGACCACCTCAGTTTG-3' (forward) and 5'-GGTGAAGGCATGGGAACATT-3' (reverse); P28, 5'-GGAGCTCGTCTTATCTCGGG-3' (forward) and 5'-TCCAAGGCTGATGATGCGAA-3' (reverse); P40, 5'-GGCCAGTACACCTGTCACAA-3' (forward) and 5'-CTGATTGTCGTCAGCCACCA-3' (reverse); STAT1, 5'-TGTATGCCATCCTCGAGAGC $-3^{\prime}$ (forward) and 
5'-AGACATCCTGCCACCTTGTG-3' (reverse); STAT3, 5'-ACTTCTTCACTAAGCCGCCA-3' (forward) and 5'-CCATGTGATCTGACACCCTG-3' (reverse); STAT4, 5'-GAATTGGAGCCCAGTAAGGTC-3' (forward) and $5^{\prime}$-ATTCCACTGAGACATGCTGGA-3' (reverse); GAPDH, 5'-ATTCCACCCATGGCAAATTC-3' (forward) and 5'-GCATCGCCCCACTTGATT-3' (reverse).

\section{ELISA, immunoprecipitation, and immunohistochemical and immunofluorescence staining to detect human IL-35}

Colorectal cancer, tumor-adjacent tissues and mucosal tissues $(200 \mathrm{mg}$ ) were lysed in lysis buffer (Beyotime) gently using a MACS Dissociator (Miltenyi Biotec), and protein lysis supernatants were collected for analysis. Serum and tissue lysis supernatants were immunoprecipitated with anti-human IL-12A antibodies (P35 H-197:sc-7925; Santa Cruz) overnight and then coupled to protein A/G-Agarose beads (sc2003 Santa Cruz) for 4 hours. Immunoprecipitates were resolved using SDS-PAGE, and blots were probed using monoclonal anti-human EBI3 antibodies (EBI3 H-6:sc-365342; Santa Cruz). A human IL-35 ELISA kit (Biolegend) was used to determine the concentration of IL-35 in serum and protein lysates derived from tissues. For immunohistochemical analysis, formalinfixed, paraffin-embedded clinical tissue sections were prepared and stained using human IL-35 antibodies and a VECTASTAIN Elite ABC kit (Vector Laboratories) according to the manufacturer's protocol. Mouse antihuman IL-35 monoclonal antibodies (1:300, 15K8D10; IMGENEX) was used as the primary antibody. Cells expressing cytoplasmic IL-35 were counted for scoring in lymphocytes. The intensity of immunoreactivity was graded on a scale from 0 (no staining) to 3 (strong immunoreactivity), and the proportion of stained cells ( 0 , no staining; $1,1-25 \%$ staining; $2,26-50 \%$ staining; $3,51-75 \%$ staining; and $4,76-100 \%$ staining) was determined. The total score was determined using the staining intensity plus the percentage of positive cells as follows: low expression group (total score $<1$ ) and high expression group (total score $\geq 1$ ) to better analyze prognoses between groups. All slides were evaluated by two pathologists. For immunofluorescence staining, colorectal tissue frozen sections were stained with antiIL-35 (1:100) and anti-CD4 (1:100, Santa Cruz, CA, USA) primary antibodies. They were then exposed to Alexa Fluor 568/488-conjugated secondary antibodies and counterstained using DAPI. Slices were visualized using a fluorescence microscope (Olympus Corp, Tokyo, Japan).

\section{In vitro cell culture}

For cell sorting, $10 \mathrm{ml}$ of peripheral blood was collected from either HDs or patients, and $\mathrm{CD} 4^{+} \mathrm{T}$ cells and $\mathrm{CD} 4{ }^{+} \mathrm{CD} 25^{-} \mathrm{T}$ cells were obtained from PBLs using a human $\mathrm{CD} 4^{+} \mathrm{T}$ Cell Isolation Kit II and a CD4 $4^{+} \mathrm{CD} 25^{+}$ Regulatory $\mathrm{T}$ Cell Isolation Kit (Miltenyi Biotec), respectively. The purity of the cells was $90 \%$ or greater, as determined by repeated analysis. The cells were incubated with rhIL-35 (Sino Biological Inc., Beijing, China) at a final concentration $100 \mathrm{nM}$ or in PBS, which was used as the control, and stimulated with pre-coated $5 \mu \mathrm{g} / \mathrm{ml} \alpha \mathrm{CD} 3$, soluble $5 \mu \mathrm{g} / \mathrm{ml} \alpha \mathrm{CD} 28$ and $200 \mathrm{U} / \mathrm{ml}$ rhIL-2 at $1 \times 10^{5}$ per well in 96-well U-bottom plates. Three replicates were performed for each condition. The cells were cultured in a humidified $\mathrm{CO}_{2}$-containing atmosphere at $37^{\circ} \mathrm{C}$ for 5-7 days in complete RPMI-10 medium supplemented with $100 \mathrm{U} / \mathrm{ml}$ penicillin, $100 \mu \mathrm{g} / \mathrm{ml}$ streptomycin, 0.5 $\mathrm{mM}$ sodium pyruvate, $0.05 \mathrm{mM}$ nonessential amino acids, $2 \mathrm{mM}$ L-glutamine, and $10 \mathrm{mM}$ HEPES (all from GIBCO). Inducible IL-35-secreting regulatory $\mathrm{T}$ cell culture experiments were performed using a transwell co-culture system $(0.4 \mu \mathrm{m})$. A mouse monoclonal antibody for IL-35 (V1.4F5.25, Shenandoah) was used to functionally block rhIL-35. For cell proliferation experiments, purified $\mathrm{T}$ cells were stained with CFSE, and cell division was detected using flow cytometry after 5 days of incubation.

\section{Western blot analysis}

Total protein was extracted from PMBCs or $\mathrm{CD}^{+}$ $\mathrm{T}$ cells that were cultured with rhIL-35 or anti-IL-35neutralizaing monoclonal antibodies. Cell homogenates were boiled, and the proteins were separated using SDS-PAGE. After overnight incubation at $4^{\circ} \mathrm{C}$ with antiphospho-STAT1 (Tyr701, 58D6), anti-STAT1 (9H2), antiphospho-STAT3 (Tyr705, D3A7), anti-STAT3 (124H6), anti-phospho-STAT4 (Tyr693, D2E4), anti-STAT4 (2A2), anti-phospho-STAT5 (Tyr694, D47E7), anti-STAT5 (3H7), anti-phospho-JAK1 (Tyr1022/1023), anti-JAK1 (6G4), anti-phospho-JAK2 (Tyr1007/1008, C80C3), or antiJAK2 (D2E12) antibodies (all Cell Signaling Technology, Beverly, MA), the membranes were incubated with IRDye 800 goat anti-rabbit or IRDye 680 goat antimouse secondary antibodies (both LI-COR Biosciences, Lincoln, NE, USA). The targeted proteins were detected and quantified using a Li-COR Odyssey infrared imaging system (LI-COR Biosciences).

\section{EBI3 promoter activity detected using luciferase assays}

A fragment containing the EBI3 promoter (bp -450 to +8 UTR with respect to the transcription initiation site) was ligated into the promoterless luciferase $(\mathrm{luc}+)$ vector pGL3 basic (Promega) (Supplementary Table S1 and Supplementary Figure S3A and S3B). The NF- $\kappa B$ luciferase reporter plasmid was a gift from Dr. Guohua Xie. All constructs used in this study were verified using restriction map and sequencing analyses. A total of $2 \mathrm{mg}$ of the EBI3 promoter- 
containing, NF- $\mathrm{KB}$ promoter-containing and mock plasmids were transferred into human pan $\mathrm{T}$ cells using electroporation. The efficiency of transfection into primary cells was shown by GFP expression in fluorescency microscopy (Supplementary Figure 3C). After $4 \mathrm{~h}, 8 \mathrm{~h}$ and $24 \mathrm{~h}$ hours of incubation with $200 \mathrm{ng} / \mathrm{ml} \mathrm{IL-35,} \mathrm{the} \mathrm{transcriptional} \mathrm{activity} \mathrm{induced}$ by each gene promoter was determined using a DualLuciferase Reporter Assay System (Promega) according to the manufacturer's instructions .

\section{Statistics}

Statistical evaluations were performed using GraphPad Prism (version 5.0). Values are shown throughout the manuscript as the mean \pm SEM except for the patients and the HD ages, which are shown as the mean $\pm \mathrm{SD}$. Student's $t$-tests were used to analyze the differences between the groups, and one-way ANOVA was initially performed to determine whether an overall statistically significant difference was present before two-tailed paired or unpaired Student's $t$-tests were used for normally distributed data. In cases where there was a significant difference between subgroups, post hoc analyses were performed based on the Tukey test (for normally distributed data) or the Mann-Whitney $U$-test. KaplanMeier survival curves were plotted, and log rank tests were performed. The significance of various variables related to survival was analyzed using the Cox proportional hazards model in a multivariate analysis. A $p$ value of $<0.05$ was considered to be statistically significant.

\section{CONFLICTS OF INTEREST}

The authors declare that there are no conflicts of interests regarding the publication of this paper.

\section{GRANT SUPPORT}

This work was supported by the National Natural Science Foundation of China (81201768, 81372641, 81401946 and 81101848), the Basic Research Project of Shanghai Science and Technology Commission (14DZ1940200) and the Science Foundation of Shanghai Jiaotong University School of Medicine (12XJ10023).

\section{Authors' contributions} work.

Yanhui Ma and Lei Chen contributed equally to this

\section{REFERENCES}

1. Estimated cancer incidence, mortality and prevalence worldwide in 2012.
2. Siegel RL, Miller KD, Jemal A. Cancer statistics. CA Cancer J Clin. 2015; 65:5-29.

3. Weitz J, Koch M, Debus J, Hohler T, Galle PR, Buchler MW. Colorectal cancer. Lancet. 2005; 365:153-165.

4. Hanahan D, Weinberg RA. Hallmarks of cancer: the next generation. Cell. 2011; 144:646-674.

5. Sakaguchi S, Sakaguchi N, Shimizu J, Yamazaki S, Sakihama T, Itoh M, Kuniyasu Y, Nomura T, Toda M, Takahashi T. Immunologic tolerance maintained by CD25+ CD4+ regulatory T cells: their common role in controlling autoimmunity, tumor immunity, and transplantation tolerance. Immunol Rev. 2001; 182:18-32.

6. Shevach EM, DiPaolo RA, Andersson J, Zhao DM, Stephens GL, Thornton AM. The lifestyle of naturally occurring CD4+ CD25+ Foxp3+ regulatory $\mathrm{T}$ cells. Immunol Rev. 2006; 212:60-73.

7. Le Gouvello S, Bastuji-Garin S, Aloulou N, Mansour H, Chaumette MT, Berrehar F, Seikour A, Charachon A, Karoui M, Leroy K, Farcet JP, Sobhani I. High prevalence of Foxp3 and IL17 in MMR-proficient colorectal carcinomas. Gut. 2008; 57:772-779.

8. Ling KL, Pratap SE, Bates GJ, Singh B, Mortensen NJ, George BD, Warren BF, Piris J, Roncador G, Fox SB, Banham $\mathrm{AH}$, Cerundolo $\mathrm{V}$. Increased frequency of regulatory $\mathrm{T}$ cells in peripheral blood and tumour infiltrating lymphocytes in colorectal cancer patients. Cancer Immun. 2007; 7:7.

9. Michel S, Benner A, Tariverdian M, Wentzensen N, Hoefler P, Pommerencke T, Grabe N, von Knebel Doeberitz M, Kloor M. High density of FOXP3-positive T cells infiltrating colorectal cancers with microsatellite instability. Br J Cancer. 2008; 99:1867-1873.

10. Collison LW, Workman CJ, Kuo TT, Boyd K, Wang Y, Vignali KM, Cross R, Sehy D, Blumberg RS, Vignali DA. The inhibitory cytokine IL-35 contributes to regulatory T-cell function. Nature. 2007; 450:566-569.

11. Niedbala W, Wei XQ, Cai B, Hueber AJ, Leung BP, McInnes IB, Liew FY. IL-35 is a novel cytokine with therapeutic effects against collagen-induced arthritis through the expansion of regulatory $\mathrm{T}$ cells and suppression of Th17 cells. Eur J Immunol. 2007; 37:3021-3029.

12. Shen P, Roch T, Lampropoulou V, O'Connor RA, Stervbo U, Hilgenberg E, Ries S, Dang VD, Jaimes Y, Daridon C, Li R, Jouneau L, Boudinot P, et al. IL-35-producing B cells are critical regulators of immunity during autoimmune and infectious diseases. Nature. 2014; 507:366-370.

13. Wang Z, Liu JQ, Liu Z, Shen R, Zhang G, Xu J, Basu S, Feng Y, Bai XF. Tumor-derived IL-35 promotes tumor growth by enhancing myeloid cell accumulation and angiogenesis. J Immunol. 2013; 190:2415-2423.

14. Xiang XG, Xie Q. IL-35: a potential therapeutic target for controlling hepatitis B virus infection. J Dig Dis. 2015; 16:1-6. 
15. Jin P, Ren H, Sun W, Xin W, Zhang H, Hao J. Circulating IL-35 in pancreatic ductal adenocarcinoma patients. Hum Immunol. 2014; 75:29-33.

16. Liao KL, Bai XF, Friedman A. Mathematical modeling of Interleukin-35 promoting tumor growth and angiogenesis. PLoS One. 2014; 9:e110126.

17. Yang J, Yang M, Htut TM, Ouyang X, Hanidu A, Li X, Sellati R, Jiang H, Zhang S, Li H, Zhao J, Ting AT, Mayer L, et al. Epstein-Barr virus-induced gene 3 negatively regulates IL-17, IL-22 and RORgamma t. Eur J Immunol. 2008; 38:1204-1214.

18. Collison LW, Chaturvedi V, Henderson AL, Giacomin PR, Guy C, Bankoti J, Finkelstein D, Forbes K, Workman CJ, Brown SA, Rehg JE, Jones ML, Ni HT, et al. IL-35-mediated induction of a potent regulatory $\mathrm{T}$ cell population. Nat Immunol. 2010; 11:1093-1101.

19. Sha X, Meng S, Li X, Xi H, Maddaloni M, Pascual DW, Shan H, Jiang X, Wang H, Yang XF. Interleukin-35 Inhibits Endothelial Cell Activation by Suppressing MAPK-AP-1 Pathway. J Biol Chem. 2015; 290:19307-19318.

20. Collison LW, Delgoffe GM, Guy CS, Vignali KM, Chaturvedi V, Fairweather D, Satoskar AR, Garcia KC, Hunter CA, Drake CG, Murray PJ, Vignali DA. The composition and signaling of the IL-35 receptor are unconventional. Nat Immunol. 2012; 13:290-299.

21. Wang RX, Yu CR, Dambuza IM, Mahdi RM, Dolinska MB, Sergeev YV, Wingfield PT, Kim SH, Egwuagu CE. Interleukin-35 induces regulatory $\mathrm{B}$ cells that suppress autoimmune disease. Nat Med. 2014; 20:633-641.

22. Chen W. Cancer statistics: updated cancer burden in China. Chin J Cancer Res. 2015; 27:1.

23. Chen W, Zheng R, Zeng H, Zhang S. The updated incidences and mortalities of major cancers in China, 2011. Chin J Cancer. 2015; 34:53.

24. Li X, Mai J, Virtue A, Yin Y, Gong R, Sha X, Gutchigian S, Frisch A, Hodge I, Jiang X, Wang H, Yang XF. IL-35 is a novel responsive anti-inflammatory cytokine - a new system of categorizing anti-inflammatory cytokines. PLoS One. 2012; 7:e33628.

25. Egwuagu CE, Yu CR, Sun L, Wang R. Interleukin 35: Critical regulator of immunity and lymphocyte-mediated diseases. Cytokine Growth Factor Rev. 2015; 26:587-593.

26. Gately MK, Renzetti LM, Magram J, Stern AS, Adorini L, Gubler U, Presky DH. The interleukin-12/interleukin-12receptor system: role in normal and pathologic immune responses. Annu Rev Immunol. 1998; 16:495-521.

27. Vignali DA, Kuchroo VK. IL-12 family cytokines: immunological playmakers. Nat Immunol. 2012; 13:722-728.

28. Kastelein RA, Hunter CA, Cua DJ. Discovery and biology of IL-23 and IL-27: related but functionally distinct regulators of inflammation. Annu Rev Immunol. 2007; 25:221-242.
29. Huang CH, Loo EX, Kuo IC, Soh GH, Goh DL, Lee BW, Chua KY. Airway inflammation and IgE production induced by dust mite allergen-specific memory/effector Th2 cell line can be effectively attenuated by IL-35. J Immunol. 2011; 187:462-471.

30. Whitehead GS, Wilson RH, Nakano K, Burch LH, Nakano H, Cook DN. IL-35 production by inducible costimulator (ICOS)-positive regulatory $\mathrm{T}$ cells reverses established IL-17-dependent allergic airways disease. J Allergy Clin Immunol. 2012; 129:207-215 e201-205.

31. Liu F, Tong F, He Y, Liu H. Detectable expression of IL-35 in CD4+ T cells from peripheral blood of chronic hepatitis B patients. Clin Immunol. 2011; 139:1-5.

32. Yue CY, Zhang B, Ying CM. Elevated Serum Level of IL-35 Associated with the Maintenance of Maternal-Fetal Immune Tolerance in Normal Pregnancy. PLoS One. 2015; 10:e0128219.

33. Cao J, Xu F, Lin S, Tao X, Xiang Y, Lai X, Zhang L. IL-35 is elevated in clinical and experimental sepsis and mediates inflammation. Clin Immunol. 2015; 161:89-95.

34. Nakano S, Morimoto S, Suzuki S, Tsushima H, Yamanaka K, Sekigawa I, Takasaki Y. Immunoregulatory role of IL-35 in $\mathrm{T}$ cells of patients with rheumatoid arthritis. Rheumatology (Oxford). 2015; 54:1498-1506.

35. Olson BM, Sullivan JA, Burlingham WJ. Interleukin 35: a key mediator of suppression and the propagation of infectious tolerance. Front Immunol. 2013; 4:315.

36. Seyerl M, Kirchberger S, Majdic O, Seipelt J, Jindra C, Schrauf C, Stockl J. Human rhinoviruses induce IL-35producing Treg via induction of B7-H1 (CD274) and sialoadhesin (CD169) on DC. Eur J Immunol. 2010; 40:321-329.

37. Trinchieri G, Pflanz S, Kastelein RA. The IL-12 family of heterodimeric cytokines: new players in the regulation of $\mathrm{T}$ cell responses. Immunity. 2003; 19:641-644.

38. Sun L, He C, Nair L, Yeung J, Egwuagu CE. Interleukin 12 (IL-12) family cytokines: Role in immune pathogenesis and treatment of CNS autoimmune disease. Cytokine. 2015; 75:249-255.

39. Wirtz S, Becker C, Fantini MC, Nieuwenhuis EE, Tubbe I, Galle PR, Schild HJ, Birkenbach M, Blumberg RS, Neurath MF. EBV-induced gene 3 transcription is induced by TLR signaling in primary dendritic cells via NF-kappa B activation. J Immunol. 2005; 174:2814-2824.

40. Ma YH, Zhou YL, Yue CY, Zhang GH, Deng L, Xie GH, $\mathrm{Xu}$ WP, Shen LS. Vitamin D deficiency contributes to the reduction and impaired function of naive CD45RA(+) regulatory $\mathrm{T}$ cell in chronic heart failure. J Immunol Res. 2015; 2015:547697. 